\title{
META-ANALISIS SKRIPSI MAHASISWA PENDIDIKAN FISIKA FKIP UNTAN TENTANG MODEL PEMBELAJARAN DIRECT INSTRUCTION
}

\author{
${ }^{1 *}$ Teja Putri Solihan , ${ }^{2}$ Stepanus Sahala Sitompu, ${ }^{3}$ Syaiful B. Arsyid \\ 1,2,3 Program Studi Pendidikan Fisika FKIP UNTAN Pontianak Pontianak
}

*Email Korespondensi: tejaputrisolihan@gmail.com

\section{INFO ARTIKEL}

Diterima : 21 November 2020

Direvisi : -

Dipublikasikan : 31 Juli 2021

\begin{abstract}
This meta-analysis aims to determine the effect of research characteristics on the effect size of the direct instruction learning model in the undergraduate thesis of the Physics Education Study Program FKIP UNTAN, published in 2016-2019. This type of research is a survey research with purposive sampling technique consisting of 6 theses. Data collection techniques in this research are documentary studies. The results of undergraduate thesis Physics Education study programs that use the direct instruction learning model obtained an average effect size of 1.00 which high effectiveness categories based on the John Hattie barometer. In this study, there are 2 characteristics of researchers examined, among others: the gender of the researcher and Grade Point Average (GPA) of the researcher. Based on the 2 characteristics of the researchers, it did not have a significant effect on the effect size of the undergraduate students' thesis in the Physics Education study program that uses the direct instruction learning model. In this study there were 13 characteristics of the methodology studied including: research location, school level, sample size, number of classes, number of meetings, material sub-fields, learning tools or media, test reliability coefficient, instrument validity, test forms, forms of research, designs experiments, and data collection tools. Of the 13 characteristics of the methodology, it did not have a significant effect on the effect size of the undergraduate students' thesis in the Physics Education study program that used the direct instruction learning model.
\end{abstract}

\section{Pendahuluan}

Jurnal JIPPF adalah jurnal yang mempublikasikan artikel-artikel ilmiah dibidang ilmu Fisika dan kependidikan Fisika-diterbitkan oleh program studi pendidikan Fisika FKIP Universitas Tanjungpura. Artikel-artikel yang dipublikasikan di jurnal JIPPF dapat berbentuk artikel hasil penelitian maupun short communication. Artikel-artikel yang dimuat di jurnal JIPPF adalah artikel yang telah melalui proses penelaahan oleh Mitra Bestari (peer-reviewers). Proses penelaahan artikel dilakukan dengan metode single blind review.

Beberapa menganggap fisika sebagai sains atau ilmu pengetahuan paling fundamental karena merupakan dasar dari semua bidang sains yang lain. Fisika berhubungan dengan materi dan energi, dengan hukum-hukum yang mengatur gerakan partikel dan gelombang, dengan interaksi antarpartikel, dan dengan sifat-sifat molekul, atom dan inti atom, dan dengan sistem berskala lebih besar seperti gas, zat cair, dan zat padat (Tipler, 1998: 1). Menurut Arends (dalam Anon, 2016) direct instruction adalah suatu model pembelajaran yang dirancang khusus untuk menunjang proses belajar siswa yang berkaitan dengan pengetahuan deklaratif dan pengetahuan prosedural yang terstruktur dengan baik, dapat diajarkan dengan pola kegiatan yang bertahap selangkah demi selangkah.

Model pembelajaran direct instruction dilandasi oleh teori belajar perilaku yang beranggapan bahwa belajar bergantung pada pengalaman termasuk pemberian umpan balik. Umpan balik kepada siswa dalam pembelajaran berupa penguatan terhadap materi yang diajarkan. Adapun langkah-langkah pada model pembelajaran direct instruction yaitu: 1) fase orientasi, 2) fase presentase atau demonstrasi, 3) fase latihan terbimbing, 4) fase menganalisis pemahaman dan memberikan umpan balik, dan 5) fase latihan mandiri (Anon, 2016). 
Penelitian yang berfokus pada model pembelajaran direct instruction cukup banyak dilakukan oleh mahasiswa program studi Pendidikan Fisika FKIP Universitas Tanjungpura (UNTAN). Berdasarkan hasil penelusuran peneliti terhadap skripsi-skripsi mahasiswa Pendidikan Fisika FKIP UNTAN tahun 2016-2019 di UPT Perpustakaan UNTAN, terdapat 10 skripsi yang menggunakan model pembelajaran direct instruction. Oleh karena itu, model pembelajaran direct instruction menarik untuk diteliti pengaruh karakteristik penelitian terhadap effect size model pembelajaran direct instruction dalam skripsi mahasiswa S-1 program studi Pendidikan Fisika FKIP UNTAN tahun terbitan 2016-2019 dengan melakukan metode meta-analisis.

Menurut Nindrea (2016) meta-analisis dilakukan sebagai usaha untuk mendapatkan sebuah kesimpulan hasil dari berbagai studi, yang mempunyai keabsahan yang lebih tinggi secara empiris dan statistik dibandingkan dengan hanya melihat hasil dari suatu penelitian saja. Ditinjau dari prosesnya, studi meta-analisis merupakan studi yang merekapitulasi fakta tanpa memanipulasi eksperimental.

Hasil tiap studi primer dirubah ke dalam bentuk yang lebih umum, yang disebut sebagai effect size. Effect size yaitu perbedaan kejadian efek antara kelas ekperimental dan kelas kontrol. Dalam meta-analisis dilakukan penggabungan effect size tiap studi dengan bantuan statistika tertentu (Nindrea, 2016).

Dengan adanya sintesis tersebut, para peneliti dapat memperoleh informasi awal dari berbagai penelitian yang sudah dilakukan tentang suatu masalah terkait dengan masalah penelitian yang menjadi minat peneliti. Para peneliti dapat memperoleh informasi tentang isu-isu, baik yang sudah banyak dikaji maupun yang belum sama sekali. Metaanalisis yang dilakukan oleh Hattie (2018) yang berjudul Hattie Ranking: 252 Influences and Effect Sizes Related To Student Achievement dari 252 pengaruh tersebut model pembelajaran direct instruction menduduki peringkat ke48 dan memiliki effect sizes sebesar 0,6 tergolong efektivitas sedang berdasarkan barometer John Hattie.

Berdasarkan hasil penelurusan di UPT Perpustakaan UNTAN penelitian meta-analisis yang berfokus pada model pembelajaran direct instruction belum pernah diteliti lebih lanjut. Hal ini mendorong peneliti untuk melakukan metaanalisis skripsi mahasiswa Pendidikan Fisika FKIP UNTAN tentang model pembelajaran direct instruction tahun terbitan 2016-2019. Hasil dari meta-analisis ini diharapkan dapat memberikan keseragaman pandangan atas temuan secara menyeluruh.

\section{Metode Penelitian}

Metode penelitian yang digunakan pada penelitian ini adalah jenis penelitian survei. Survei merupakan cara pengumpulan data dari sejumlah unit atau individu dalam jumlah besar dan luas. Survei ditunjukkan untuk memperoleh data guna mendeskripsikan populasi (Sukardi, 2015: 193).

Populasi dalam penelitian ini adalah skripsi-skripsi mahasiswa S-1 program studi Pendidikan Fisika FKIP UNTAN tahun terbitan 2016-2019 yang menggunakan model pembelajaran direct instruction sebanyak 10 skripsi. Sampel dalam penelitian ini adalah 6 skripsi mahasiswa S-1 program studi Pendidikan Fisika FKIP UNTAN yang menggunakan model pembelajaran direct instruction tahun terbitan 2016-2019. Hal ini dikarenakan ada 3 skripsi yang tidak memiliki nilai effect size dan 1 skripsi mengalami kesalahan perhitungan effect size sehingga tidak memenuhi syarat untuk dilakukan meta-analisis.

Pengambilan sampel pada penelitian ini menggunakan sampling purposive. Sampling purposive termasuk teknik pengambilan sampel yang tidak memberi peluang atau kesempatan yang sama bagi setiap anggota populasi untuk dipilih menjadi sampel penelitian (Sugiyono, 2016). Teknik pengumpulan data dalam penelitian ini adalah studi dokumenter. Dalam melaksanakan meta-analisis skripsi, peneliti menggunakan prosedur penelitian langkah-langkah meta-analisis menurut Sutrisno, Kresnadi, dan Kartono (2017).

\section{Tahap Pelaksanaan}

Langkah-langkah dalam tahappelaksanaan meta-analisis antara lain: 1) Menetapkan domain penelitian yang dimeta-analisis. 2) Mengadakan pemilihan jenis publikasi yang dimeta-analisis. 3) Mengumpulkan data di UPT Perpustakaan UNTAN. 4) Mengadakan penelusuran sesuai dengan instrumen penelitian. Kemudian mencatat data yang diperoleh untuk dimasukkan ke dalam tabel blangko pengamatan dan tabel daftar hasil telaah skripsi hasil-hasil penelitian. 5) Memasukkan data ke dalam tabel blangko pengamatan dan tabel daftar hasil telaah skripsi hasil-hasil penelitian. 6) Mengelompokkan data sesuai dengan variabel yang di uji. 7) Menganalisis data sesuai dengan uji statistik masing-masing. 8) Menulis dan menyusun laporan hasil penelitian. 


\section{Hasil dan Pembahasan}

\subsection{Hasil}

Pada penelitian ini jumlah total skripsi yang dianalisis adalah enam skripsi mahasiswa S-1 program studi Pendidikan Fisika FKIP UNTAN terbitan 2016-2019. Adapun rinciannya ditunjukkan pada Tabel 1.

Tabel 1. Harga Effect Size Skripsi yang menggunakan Model Direct Instruction

\begin{tabular}{cccc}
\hline No & Nama Peneliti & Tahun Terbitan & Effect size \\
\hline 1 & AN & 2016 & 0,56 \\
\hline 2 & HQ & 2016 & 0,56 \\
\hline 3 & PV & 2016 & 0,64 \\
\hline 4 & FR & 2017 & 0,68 \\
\hline 5 & AS & 2018 & 0,28 \\
\hline 6 & SF & 2018 & 3,25 \\
\hline \multicolumn{5}{r}{} & EES & 5,97 \\
\hline
\end{tabular}

Berdasarkan Tabel 1. diperoleh besar effect size rata-rata untuk skripsi yang menggunakan model pembelajaran direct instruction adalah sebesar 1,00 kategori efektivitas tinggi menurut barometer John Hattie.

Tabel 2. Pengaruh Effect Size Terhadap Jenis Kelamin

\begin{tabular}{cccc}
\hline No & Jenis Kelamin & n sampel & $\overline{\boldsymbol{E S}}$ \\
\hline 1. & Laki-laki & 4 & 0,54 \\
\hline 2. & Perempuan & 2 & 1.91 \\
\hline
\end{tabular}

Berdasarkan Tabel 2. peneliti yang berjenis kelamin laki-laki berjumlah empat orang dan peneliti berjenis kelamin perempuan berjumlah dua orang. Effect size rata-rata peneliti yang berjenis kelamin laki-laki sebesar 0,54, sedangkan effect size rata-rata peneliti yang berjenis kelamin perempuan sebesar 1,91. Perhitungan uji $\quad H$ menunjukkan Asymp Sig = 0,481 >0.05 maka $\mathrm{H}_{0}$ diterima dan Ha ditolak sehingga dapat disimpulkan bahwa tidak terdapat perbedaan effect size

Tabel 3. Pengaruh Effect Size Terhadap IPK Peneliti

\begin{tabular}{clll}
\hline No & Nama peneliti & IPK peneliti & ES \\
\hline 1. & AN & 3,37 & 0,56 \\
\hline 2. & HQ & 3,44 & 0,56 \\
\hline 3. & PV & 3,08 & 0,64 \\
\hline 4. & FR & 3,25 & 0,68 \\
\hline 5. & AS & 3,01 & 0,28 \\
\hline 6. & SF & 3,71 & 3,25 \\
\hline & Rata-rata & 3,31 & 1,00 \\
\hline
\end{tabular}

Berdasarkan Tabel 3. terlihat bahwa rata-rata IPK Peneliti sebesar 3,31 dan effect size rata-rata sebesar 1,00. Perhitungan Uji Korelasi Spearman Rank diperoleh Sig. (2-tailed) =0,06 > 0,05 maka Ho diterima dan Ha ditolak sehingga dapat disimpulkan bahwa tidak terdapat hubungan yang signifikan antara Indeks Prestasi Kumulatif (IPK) dan effect size

Tabel 4. Pengaruh Effect Size Terhadap Lokasi Penelitian

\begin{tabular}{cccc}
\hline No & Lokasi Penelitian & n sampel & $\overline{\mathbf{E S}}$ \\
\hline 1 & Kota & 4 & 1,16 \\
\hline 2 & Kabupaten & 2 & 0,66
\end{tabular}

Berdasarkan Tabel 4. jumlah skripsi yang melakukan penelitian di kota sebanyak empat skripsi dengan effect size rata-rata sebesar 1,16 dan jumlah skripsi yang melakukan penelitian di kabupaten sebanyak dua skripsi 
dengan effect size rata-rata 0,66. Perhitungan uji $\mathrm{H}$ menunjukkan Asymp Sig $=0,348>0.05$ maka $\mathrm{H}_{0}$ diterima dan $\mathrm{Ha}$ ditolak sehingga dapat disimpulkan bahwa tidak terdapat perbedaan effect size yang signifikan berdasarkan lokasi penelitian.

Tabel 5. Pengaruh Effect Size Terhadap Jenjang Sekolah

\begin{tabular}{cccc}
\hline No & Jenjang sekolah sampel & n sampel & $\overline{\boldsymbol{E S}}$ \\
\hline 1. & SMP & 2 & 0,66 \\
\hline 2. & SMA & 4 & 1,16 \\
\hline
\end{tabular}

Berdasarkan Tabel 5. skripsi yang melakukan penelitian pada jenjang SMP sebanyak dua skripsi dengan effect size rata-rata sebesar 0,66, sedangkan untuk skripsi yang melakukan penelitian pada jenjang SMA sebanyak empat skripsi dengan effect size rata-rata sebesar 1,16. Uji H diperoleh Asymp Sig = 0,348 $>0.05$ maka $\mathrm{H}_{0}$ diterima dan Ha ditolak sehingga dapat disimpulkan bahwa tidak terdapat perbedaan effect size yang signifikan berdasarkan jenjang sekolah.

Tabel 6. Pengaruh Effect Size Terhadap Besar Sampel

\begin{tabular}{clll}
\hline No & Nama peneliti & Besar sampel & ES \\
\hline 1. & AN & 25 & 0,56 \\
\hline 2. & HQ & 63 & 0,56 \\
\hline 3. & PV & 30 & 0,64 \\
\hline 4. & FR & 55 & 0,68 \\
\hline 5. & AS & 71 & 0,28 \\
\hline 6. & SF & 42 & 3,25 \\
\hline & Rata-rata & 47,7 & 1,00 \\
\hline
\end{tabular}

Berdasarkan Tabel 6. terlihat bahwa jumlah sampel penelitian rata-rata sebesar 47,7 siswa dan effect size ratarata sebesar 1,00. Perhitungan uji korelasi Spearman Rank diperoleh Sig (2-tailed) $=0,678>0,05$ maka $\mathrm{H}_{0}$ diterima dan $\mathrm{Ha}$ ditolak sehingga dapat disimpulkan bahwa tidak terdapat hubungan yang signifikan antara effect size dengan besar sampel.

Tabel 7. Pengaruh Effect Size Terhadap Jumlah Kelas

\begin{tabular}{cccc}
\hline No & Jenjang Kelas & n sampel & $\overline{\mathbf{E S}}$ \\
\hline 1. & 1 KeLas & 2 & 0,60 \\
\hline 2. & 2 Kelas & 4 & 1,19
\end{tabular}

Berdasarkan Tabel 7. bahwa ada dua skripsi yang melakukan penelitian berjumlah 1 kelas dengan effect size ratarata sebesar 0,60, sedangkan ada empat skripsi yang melakukan penelitian dalam 2 kelas dengan effect size ratarata 1,19. Berdasarkan Uji H yang dilakukan Asymp Sig = 0,814 > 0.05 maka Ho diterima dan Ha ditolak sehingga dapat disimpulkan bahwa tidak terdapat perbedaan effect size yang signifikan berdasarkan jumlah kelas

Tabel 8. Pengaruh Effect Size Terhadap Jumlah Pertemuan

\begin{tabular}{cccc}
\hline No & Jumlah Pertemuan & n sampel & $\overline{\mathbf{E S}}$ \\
\hline 1 & 4 pertemuan & 5 & 1,06 \\
\hline 2 & 5 pertemuan & 1 & 0,68 \\
\hline
\end{tabular}

Berdasarkan Tabel 8. bahwa ada lima skripsi yang melakukan penelitian sebanyak 4 kali pertemuan dengan effect size rata-rata sebesar 1,06, dan ada satu peneliti yang melakukan penelitian dalam 5 kali pertemuan dengan effect size rata-rata sebesar 0,68. Analisis Uji H menunjukkan bahwa Asymp Sig =0,373>0.05 maka H0 diterima dan $\mathrm{Ha}$ ditolak sehingga dapat disimpulkan bahwa tidak terdapat perbedaan effect size yang signifikan berdasarkan jumlah pertemuan. 
Tabel 9. Pengaruh Effect Size Terhadap Sub Bidang Materi

\begin{tabular}{cccc}
\hline No & Sub bidang materi & n sampel & $\overline{\mathbf{E S}}$ \\
\hline 1 & Termodinamika & 2 & 0,62 \\
\hline 2 & Mekanika & 4 & 1,18 \\
\hline
\end{tabular}

Berdasarkan Tabel 9. Skripsi yang mengambil sub materi termodinamika ada dua skripsi dengan effect size ratarata sebesar 0,62, sedangkan mekanika sebanyak empat skripsi dengan effect size rata-rata sebesar 1,18. Analisis menggunakan Uji H diperoleh Asymp Sig $=0,814>0.05$ maka $\mathrm{H}_{0}$ diterima dan Ha ditolak sehingga dapat disimpulkan bahwa tidak terdapat perbedaan effect size yang signifikan berdasarkan sub bidang materi.

Tabel 10. Pengaruh Effect Size Terhadap Alat Atau Media Pembelajaran

\begin{tabular}{llll}
\hline No & Alat atau media pembelajaran & $\mathrm{n}$ sampel & ES \\
\hline 1. & Model DI tanpa berbantuan & 1 & 0,28 \\
\hline 2. & Model DI + alat peraga & 1 & 0.64 \\
\hline 3. & $\begin{array}{l}\text { Model DI }+ \text { aplikasi } \\
\text { pembelajaran }\end{array}$ & 4 & 1,26 \\
\hline
\end{tabular}

Berdasarkan Tabel 10 menunjukkan bahwa skripsi yang menggunakan model pembelajaran direct instruction tanpa berbantuan sebanyak satu skripsi dengan effect size rata-rata sebesar 0,28. Kemudian untuk skripsi yang menggunakan model pembelajaran direct instruction berbantuan alat peraga sebanyak satu orang dengan effect size rata-rata sebesar 0,64, sedangkan skripsi yang menggunakan model pembelajaran direct instruction berbantuan aplikasi pembelajaran sebanyak empat skripsi dengan effect size rata- rata sebesar 1,26. Analisis menggunakan Uji H diperoleh Asymp Sig = 0,252 > 0.05 maka HO diterima dan Ha ditolak sehingga dapat disimpulkan bahwa tidak terdapat perbedaan effect size yang signifikan berdasarkan alat atau media pembelajaran.

Tabel 11. Pengaruh Effect Size Terhadap Koefisien Reliabilitas

\begin{tabular}{clll}
\hline No & Nama Peneliti & $\begin{array}{c}\text { Koeifisien } \\
\text { reliabilitas }\end{array}$ & ES \\
\hline 1. & AN & 0,504 & 0,56 \\
\hline 2. & HQ & 0,434 & 0,56 \\
\hline 3. & PV & 0,41 & 0,64 \\
\hline 4. & FR & 0,65 & 0,68 \\
\hline 5. & AS & 0,46 & 0,28 \\
\hline 6. & SF & 0,46 & 3,25 \\
\hline & Rata-rata & 0,49 & 1,00 \\
\hline
\end{tabular}

Berdasarkan Tabel 11. diperoleh rata- rata koefisien reliabilitas tes sebesar 0,49, sedangkan effect size rata-rata dari enam skripsi sebesar 1,00. Analisis perhitungan menggunakan Uji Korelasi Spearman Rank diperoleh Sig (2-tailed) $=0,844>0,05$ maka $\mathrm{H}_{0}$ diterima dan $\mathrm{Ha}$ ditolak sehingga dapat disimpulkan bahwa tidak terdapat hubungan yang signifikan antara koefisiensi reliabilitas dan effect size.

Tabel 12. Pengaruh Effect Size Terhadap Validitas Instrumen

\begin{tabular}{clll}
\hline No & Nama Peneliti & $\begin{array}{l}\text { Validitas } \\
\text { Instrumen }\end{array}$ & ES \\
\hline 1. & AN & 4,00 & 0,56 \\
\hline 2. & $\mathrm{HQ}$ & 4,30 & 0,56 \\
\hline
\end{tabular}




\begin{tabular}{llll}
\hline 3. & PV & 3,52 & 0,64 \\
\hline 4. & FR & 3,94 & 0,68 \\
\hline 5. & AS & 3,60 & 0,28 \\
\hline 6. & SF & 3,33 & 3,25 \\
\hline & Rata-rata & 3,78 & 1,00 \\
\hline
\end{tabular}

Berdasarkan Tabel 12. rata-rata validitas instrumen sebesar 3,78 dan effect size rata-rata dari enam skripsi yang diteliti sebesar 1,00. Analisis menggunakan Uji Korelasi Spearman Rank diperoleh Sig (2-tailed) =0,225 > 0,05 maka $\mathrm{H}_{0}$ diterima dan $\mathrm{Ha}$ ditolak sehingga dapat disimpulkan bahwa tidak terdapat hubungan yang signifikan antara validitas instrumen dan effect size.

Tabel 13. Pengaruh Effect Size Terhadap Bentuk Tes

\begin{tabular}{cccc}
\hline No & Bentuk Tes & n sampel & $\overline{\mathbf{E S}}$ \\
\hline 1. & Esai & 1 & 0,28 \\
\hline 2. & Pilihan ganda+ esai & 1 & 3,25 \\
\hline 3. & $\begin{array}{c}\text { Pilihan ganda+alasan } \\
\text { terbuka }\end{array}$ & 4 & 0,61 \\
\hline
\end{tabular}

Berdasarkan Tabel 13. terdapat satu skripsi yang menggunakan bentuk tes esai dengan effect size rata-rata sebesar 0,28. Kemudian, skripsi yang menggunakan bentuk tes pilihan ganda disertai esai sebanyak satu skripsi dengan effect size rata-rata sebesar 3,25, sedangkan skripsi yang menggunakan bentuk tes pilihan ganda disertai alasan terbuka. sebanyak empat skripsi dengan effect size rata- rata sebesar 0,61. Analisis menggunakan uji $\mathrm{H}$ diperoleh Asymp Sig = 0,16 > 0.05 maka $\mathrm{H}_{0}$ diterima dan $\mathrm{Ha}$ ditolak sehingga dapat disimpulkan bahwa tidak terdapat perbedaan effect size yang signifikan berdasarkan bentuk tes.

Tabel 14. Pengaruh Effect Size Terhadap Bentuk Penelitian

\begin{tabular}{clcc}
\hline No & Bentuk penelitian & n sampel & $\overline{\boldsymbol{E S}}$ \\
\hline 1. & Pre-expremental design & 2 & 0,60 \\
\hline 2. & Quasi experimental design & 3 & 1,50 \\
\hline 3. & True experimental & 1 & 0,28 \\
\hline
\end{tabular}

Berdasarkan Tabel 14. terdapat dua skripsi yang menggunakan bentuk penelitian pre-experimental design dengan effect size rata- rata sebesar 0,60. Kemudian, skripsi yang menggunakan bentuk penelitian quasi experimental design sebanyak tiga skripsi dengan effect size rata-rata sebesar 1,50, sedangkan skripsi yang menggunakan bentuk penelitian true experimental design sebanyak satu skripsi dengan effect size rata-rata sebesar 0,28. Analisis menggunakan Uji H diperoleh Asymp Sig = 0,252 > 0.05 maka HO diterima dan Ha ditolak sehingga dapat disimpulkan bahwa tidak terdapat perbedaan effect size yang signifikan berdasarkan bentuk penelitian.

Tabel 15. Pengaruh Effect Size Terhadap Desain Percobaan

\begin{tabular}{cccc}
\hline No & Desain percobaan & n sampel & $\overline{\mathbf{E S}}$ \\
\hline 1. & $\begin{array}{c}\text { Non-equivalent } \\
\text { control group }\end{array}$ & 3 & 1,50 \\
\hline 2. & $\begin{array}{c}\text { One group pre-test } \\
\text { post-test }\end{array}$ & 2 & 0,60 \\
\hline 3. & $\begin{array}{c}\text { Pre-test post-test } \\
\text { control group }\end{array}$ & 1 & 0,28 \\
\hline
\end{tabular}

Berdasarkan Tabel 15. terdapat tiga skripsi yang menggunakan desain percobaan non-equivalent control group dengan effect size rata-rata sebesar 1,50. Kemudian, skripsi yang menggunakan desain percobaan one group pre- 
test post-test sebanyak dua skripsi dengan effect size rata-rata sebesar 0,60, sedangkan skripsi yang menggunakan desain percobaan pre-test post-test control group sebanyak satu skripsi dengan effect size rata-rata sebesar 0,28. Analisis menggunakan uji $\mathrm{H}$ diperoleh Asymp Sig = 0,252 > 0.05 maka $\mathrm{H}_{0}$ diterima dan Ha ditolak sehingga dapat disimpulkan bahwa tidak terdapat perbedaan effect size yang signifikan berdasarkan desain percobaan.

Tabel 16. Pengaruh Effect Size Terhadap Alat Pengumpul Data

\begin{tabular}{cccc}
\hline No. & Alat Pengumpulan data & n sampel & $\overline{\mathbf{E S}}$ \\
\hline 1. & Tes Diagnostik & 4 & 0,61 \\
\hline 2. & Tes Hasil Belajar & 2 & 1,77 \\
\hline
\end{tabular}

Berdasarkan Tabel 16. terdapat empat skripsi yang menggunakan tes diagnostik sebagai alat pengumpulan data dengan effect size rata-rata sebesar 0,61, sedangkan ada dua skripsi yang menggunakan tes hasil belajar sebagai alat pengumpulan data dengan effect size rata-rata sebesar 1,77. Analisis menggunakan uji H diperoleh Asymp Sig $=1,00>0.05$ maka $H_{0}$ diterima dan $\mathrm{Ha}$ ditolak sehingga dapat disimpulkan bahwa tidak terdapat perbedaan effect size yang signifikan berdasarkan alat pengumpulan data

\subsection{Pembahasan}

Penelitian ini merangkum 6 skripsi mahasiswa S-1 program studi Pendidikan Fisika FKIP UNTAN tahun terbitan 2016-2019 di UPT Perpustakaan UNTAN yang menggunakan model pembelajaran direct instruction. Terdapat 10 skripsi mahasiswa S-1 program studi Pendidikan Fisika FKIP UNTAN terbitan 2016-2019 yang menggunakan model pembelajaran direct instruction pada saat penelitian tanggal 2-6 September 2019 di UPT Perpustakaan UNTAN. Tetapi dari 10 skripsi tersebut hanya ada 6 skripsi yang memenuhi syarat untuk dijadikan sampel dalam penelitian. Ada tiga skripsi yang tidak memiliki nilai effect size sehingga tidak memenuhi syarat sebagai sampel dalam penelitian. Salah satu syarat skripsi layak untuk dijadikan sampel penelitian adalah skripsi memiliki nilai effect size. Kemudian, ada satu skripsi yang mengalami kesalahan perhitungan effect size sehingga tidak dapat dimasukkan kedalam sampel penelitian. Effect size rata-rata skripsi mahasiswa S-1 program studi pendidikan fisika FKIP UNTAN terbitan 2016-2019 yang menggunakan model pembelajaran direct instruction diperoleh rata-rata effect size sebesar 1,00 kategori efektivitas tinggi berdasarkan barometer John Hattie.

Dalam penelitian ini terdapat dua karakteristik peneliti yang diteliti antara lain: jenis kelamin peneliti dan Indeks Prestasi Kumulatif (IPK) peneliti. Dua karakteristik peneliti tersebut dianalisis menggunakan SPSS Statistic 17 diperoleh bahwa karakteristik peneliti tidak memberi pengaruh yang signifikan terhadap harga effect size skripsi mahasiswa S-1 program studi Pendidikan Fisika FKIP UNTAN terbitan 2016-2019 yang menggunakan model pembelajaran direct instruction.

Dalam penelitian ini terdapat 13 karakteristik metodologi yang diteliti antara lain: lokasi penelitian, jenjang sekolah, besar sampel, jumlah kelas, jumlah pertemuan, sub bidang materi, alat atau media pembelajaran, koefisien reliabilitas tes, validitas instrumen, bentuk tes, bentuk penelitian, desain percobaan, dan alat pengumpulan data. Dari 13 karakteristik metodologi tersebut dianalisis menggunakan SPSS Statistic 17 diperoleh bahwa karakteristik metodologi tidak memberi pengaruh yang signifikan terhadap effect size skripsi mahasiswa S-1 program studi Pendidikan Fisika FKIP UNTAN terbitan 2016-2019 yang menggunakan model pembelajaran direct instruction.

\section{Kesimpulan}

Berdasarkan analisis data yang telah dilakukan, maka dapat dituliskan beberapa temuan-temuan penelitian ini, sebagai berikut: 1) Effect size rata-rata skripsi mahasiswa S-1 program studi Pendidikan Fisika FKIP UNTAN terbitan 2016-2019 yang menggunakan model pembelajaran direct instruction diperoleh rata- rata effect size sebesar 1,00 kategori efektivitas tinggi berdasarkan barometer John Hattie. 2) Dalam penelitian ini terdapat 2 karakteristik peneliti yang diteliti antara lain: jenis kelamin peneliti dan Indeks Prestasi Kumulatif (IPK) peneliti. Berdasarkan 2 karakteristik peneliti tersebut tidak memberi pengaruh yang signifikan terhadap effect size skripsi mahasiswa S-1 program studi Pendidikan Fisika FKIP UNTAN terbitan 2016-2019 yang menggunakan model pembelajaran direct instruction. 3) 
Dalam penelitian ini terdapat 13 karakteristik metodologi yang diteliti antara lain: lokasi penelitian, jenjang sekolah, besar sampel, jumlah kelas, jumlah pertemuan, sub bidang materi, alat atau media pembelajaran, koefisien reliabilitas tes, validitas instrumen, bentuk tes, bentuk penelitian, desain percobaan, dan alat pengumpulan data. Dari 13 karakteristik metodologi tersebut tidak memberi pengaruh yang signifikan terhadap effect size skripsi mahasiswa S-1 program studi Pendidikan Fisika FKIP UNTAN terbitan 2016-2019 yang menggunakan model pembelajaran direct instruction.

\section{Referensi}

Anon. (2016). Remediasi Miskonsepsi pada Perpindahan Kalor Menggunakan Model Direct Instruction Berbantuan Media Animasi di MAN. Skripsi. Pontianak: FKIP UNTAN.

Hattie, John. (2018). Hattie Ranking: 252 Influences And Effect Sizes Related To Student Achievement. (Online) https://visible-learning.org/hattie-ranking-influences-effect-sizes- learning-achievement/, diakses 20 Juli 2019).

Nindrea, R. D. (2016). Pengantar Langkah-langkah Praktis Studi Meta Analisis. Yogyakarta: Gosyen Publishing.

Sugiyono. (2016). Statistika untuk Penelitian. Bandung: Penerbit Alfabeta.

Sukardi. (2015). Metode Penelitian Pendidikan (Pendekatan Kuantitatif, Kualitatif, dan R\&D). Bandung: Penerbit Alfabeta.

Sutrisno, L., Kresnadi, H., \& Kartono. (2007). Pengembangan Pembelajaran IPA SD. LPJJ: PGSD.

Tipler, Paul A. (1998). Fisika untuk Sains dan Teknik Jilid 1. Edisi 3. Cetakan 3. Jakarta: Erlangga. 